\title{
Tuva Türkçesinde İşlevsel Dilbilgisi'ne Göre İşteşliğin Anlambilimsel Yönü
}

\author{
Semantic Aspect of Reciprocal in Terms of Functional Grammar in Tuvan Turkish
}

\author{
Tuğba Sarıkaya Aksoy \\ Dr., Ankara / Türkiye \\ e-posta tsarikaya88@gmail.com \\ orcid 0000-0002-6622-8783 \\ doi $\quad 10.54316 /$ dilarastirmalari.1012228
}

Atıf

Citation

Sarıkaya Aksoy, Tuğba (2021). Tuva Türkçesinde İşlevsel Dilbilgisi'ne Göre İşteşliğin Anlambilimsel Yönü.

Dil Araştırmaları, 29: 197-210

\section{Başvuru}

Submitted

19.10.2021

\section{Revizyon}

Revised

29.10.2021

\section{Kabul}

Accepted

01.11.2021

\section{Çevrimiçi Yayın}

Published Online

30.11.2021
Öz

Bu çalışmada Türk dilinin Kuzeydoğu alanı içinde yer alan Türk lehçelerinden biri olan Tuva Türkçesinde işteşlik kategorisinin anlambilimsel yönü İ̧slevsel Dilbilgisi kuramına göre incelenmiştir. Işlevsel Dilbilgisi, dilin yapısal birimlerinin bağlam içindeki işlevlerini ve kullanımlarını anlambilimsel, sözdizimsel ve edimbilimsel olmak üzere üç ayrı düzlemde inceler. Bir yüklemin biçimsel ve anlamsal özelliklerinin somut ve soyut cümle yapılarıyla kodlanması olay durumu olarak adlandırılır. Olay durumu türleri süreç, durum, hareket ve konum aracılığıyla açıklanır. Olay durumları devingenlik, denetleme, bitmişlik, anlık ve deneyim olmak üzere beş değişkene sahiptir.

İşteşlik, bir eylemin birden fazla katılımcı tarafından birlikte, ortaklaşa, karşılıklı veya yardımlaşarak yapıldığını gösteren bir kategoridir ve bu kategorinin biçimbirimsel, sözlüksel, sözdizimsel ve anlambilimsel düzlemleri bulunmaktadır. Çalışmada Tuva Türkçesi edebî metinlerinden seçilen örneklem doğrultusunda işteşliğin anlambilimsel düzlemde tespit edilen doğrudan (karşılıklılık, birliktelik, topluluk, yardımlaşma) ve dolaylı (mücadele etme, meydan okuma, zorlama, zttlık) işteşlik işlevleri olay durumu değişkenlerine göre ele alınmıştır.

Anahtar Kelimeler: Tuva Türkçesi, İşlevsel Dilbilgisi, işteşlik, anlambilimsel düzlem, olay durumu

\footnotetext{
ABSTRACT

In this study, the semantic aspect of the reciprocal category in Tuvan Turkish, which is one of the Turkish dialects in the Northeast area of the Turkish language, is analyzed in terms of Functional Grammar theory. Functional Grammar analyzes functions and usages of the structural units of the language in context at three different levels as being semantic, syntactic and pragmatic. Coding of the formal and semantic features of a predicate with concrete and abstract sentence structures is called action state. Action state types are described through process, status, motion,
} 
and location. Action states have five variables as being mobility, control, completion, momentary, and experience.

Reciprocal is a category showing that an action is performed by more than one participant together, jointly, mutually or cooperatively; and this category has morphemic, lexical, syntactic and semantic levels. In the study, direct (reciprocity, sociative, comitative, assistive) and indirect (struggle, challenge, coercion, opposition) reciprocal functions, which are determined in the semantic level of the reciprocal in line with the sample selected from literary works in Tuvan Turkish, are discussed in terms of action state.

Keywords: Tuvan Turkish, Functional Grammar, reciprocal, semantic level, action state

\section{Giriş}

Tuva Türkçesi, Türk lehçelerinin Kuzeydoğu grubunda Altay, Hakas, Şor, Tofa, Çulım ve Saha Türkçesiyle birlikte Sibirya grubu Türk lehçeleri içindedir. Bu makalede Tuva Türkçesinde işteş çatı biçimbirimini almış eylemlerin bağlam içinde kazandıkları anlamlar İşlevsel Dilbilgisi'ne (Functional Grammar) göre eş zamanlı bir bakış açısıyla ele alınmaktadır.

İşlev, bir parçanın bir başka parça ile veya parçaların bütün ile ilişkisi, varlıkların eylem ile olan ilişkisinde ortaya çıkan genel bilgilerin adlarıdır. Işslevsel Dilbilgisi, dillerin biçimbirimleri ve yapılarının işlevleri üzerine odaklanır ve dil öğeleri arasındaki ilişkileri, iletişimdeki işlevleri açısından ele alır. Ayrıca Işslevsel Dilbilgisi ile dili kendi içinde incelemek ve dilin toplumla ve dil dış1 somut etkenlerle olan ilişkilerini göz önünde tutarak ele almak mümkündür (Karaağaç 2018: 507).

Tuva Türkçesinde -ş- işteşlik biçimbirimini alan eylemlerin bağlam içinde karşılıklılık, birliktelik, topluluk ve yardımlaşma anlamlarını içeren doğrudan işteşlik ve mücadele etme, meydan okuma, zorlama ve zıtlık anlamlarını içeren dolaylı işteşlik işlevleri taşıdığı söylenebilir. Bu kapsamda öncelikle İşlevsel Dilbilgisi, anlambilimsel düzlem ve işteşlik hakkında kısaca teorik bilgi verilecek, ardından Tuva Türkçesi edebî metinlerinden taranmış işteşlik biçimbirimini almış eylemlerin bağlam içindeki durumu anlambilimsel düzlemin olay durumu türlerine göre incelenecektir.

\section{1. İşlevsel Dilbilgisi}

İşlevsel Dilbilgisi, Simon C. Dik tarafından 1978 yılında geliştirilen dilin doğasına işlevsel açıdan bakmaya dayanan genel bir kuramdır. Bu kuram Chomsky'nin Üretici Dönüşümsel Dilbilgisi kuramına dayanır. İşlevsel Dilbilgisi yapıda değil bağlamda görülen yüklemlemeyi temel alır (Eggins 1994: 11). Dili daha geniş açıdan ve edimsel olarak işleyen bir kuramdır. Dilin dilsel ifadelerini tipolojik, psikolojik ve edimbilimsel açıdan yeterli biçimde tanımlamaya ve açıklamaya çalışır. Işslevsel Dilbilgisi, bu yeterlilikler yanında bir dili soyutluk, somutluk ve uygulanabilirlik düzlemlerinde bazı ilkelerle de açıklayabilir (Dik 1989: 12-16).

Bir dil farklı yaklaşım biçimleriyle çeşitli şekillerde incelenebilir. Buna göre biçimsel yaklaşımda dil, soyut, biçimsel bir nesne gibi algılanır ve dilbilgisi bu 
biçimsel nesneyi anlamdan ve kullanımdan bağımsız olarak tanımlamaya çalışır. Sözdizimi yöntem olarak anlambilim ve edimbilimden daha önceliklidir (Nuyts 1983: 371; Dik 1989: 2). İşlevsel yaklaşımda ise dil, insanlar arasında iletişimsel ilişkiler için kullanılan sosyal etkileşim aracı olarak algılanır. Dil aracılığıyla sosyal etkileşim en az iki katılımcı gerektirir. Katılımcılar kurallar ve ilkelerle oluşan dilsel ifadelerden yararlanırlar (Halliday ve Matthiessen 2004: 20).

İşlevsel yaklaşımda dil, öncelikle toplumsal bir etkileşim aracı olup en belirgin işlevi bildirişimi sağlamaktır. Dildeki yapısal düzenlemelerde toplumsal etkileşim önemlidir. Işslevsel Dilbilgisi'nin öncelikli ilkesi, işlevden dolayısıyla anlamdan biçime doğru yönelmektir. Dolayısıyla, bu yaklaşımda dil yapısı sadece biçimsel boyut ile sinırlandırılamaz (Aksan 1983: 193-194; Musaoğlu 2003: 22-25).

İşlevsel Dilbilgisi, dilin işlevsel kavramlarını anlambilimsel, sözdizimsel ve edimbilimsel olmak üzere üç ayrı düzlemde inceler:

I. Anlambilimsel düzlem: Yüklemin belirlediği olay durumunda yer alan üyelerin rollerini belirler. $\mathrm{Bu}$ roller kllıcı, erek, alıcı, yararlanıcı, konum ve zaman gibi anlamsal rollerdir.

II. Sözdizimsel düzlem: Olay durumunun dilsel ifadeye yansıtılmasındaki bakış açısını gösteren özne ve nesne gibi sözdizimsel işlevlerdir.

III. Edimbilimsel düzlem: Konuşucu ve dinleyicinin iletişim ortamındaki bilgi ilişkisini sunan tema, konu ve odak gibi edimbilimsel işlevlerdir (Dik 1978: 3).

Bir cümlenin biçimsel ve anlamsal özellikleri anlatım kuralları ile ilişkili olan dilsel anlatımın gerçek biçimlerinden oluşan somut ve soyut cümle yapılarıyla tanımlanabilir. Olayların bu şekilde dilde kodlanması olay durumu olarak adlandırılır (Dik 1989: 46). Bir cümle için gerekli olan ilk üye yüklemdir. Cümlenin yüklemine yüklemin istediği türde ve sayıda üye yüklenebilir. Örneğin al- eylemi alan, alınan şey ve verici olmak üzere üç üyeye sahip olabilir. Ayşe[alan] arkadaşından[verici] kitabı[alınan şey] aldl. örneğinde al- eylemi yüklemleme olayını gerçekleştirmiştir ve bu eylem yanındaki üyelerle birlikte yüklem çerçevesini oluşturmaktadır. Buna göre Ayşe[kılıcı] arkadaşından[alıcı] kitabı[erek] aldı. örneğinde bu öğeler kılıcı, alıcı ve erek anlambilimsel işlevlerini taşımaktadırlar.

İşlevsel Dilbilgisi, cümlenin biçimsel ve anlamsal özelliklerini belirleyebilmek için her cümlenin bir derin yapısı olduğunu varsayar. Derin yapıdaki cümle bazı biçimsel ve anlambilimsel katmanlar içeren soyut ve karmaşık bir yapıdadır (Dursun 2018: 20). Örneğin $o k u$ - eylemi derin yapısında okuyan ve okunan rolünde iki çekirdek üye içerir: Ayşe kitap okudu. örneğinde yüzey yapıda Ayşe[özne], okunan rolündeki üye kitap[nesne] rolündedir. Sözdizimsel düzlemde ise (1). Ayşe kitap okudu. (2). Kitap Ayşe tarafindan okundu. cümleleri aynı olay durumunun farklı bakış açılarıyla verilmiştir. Her iki cümlede de okuma eylemini gerçekleştiren kılıcı üye Ayşe, okunan şey ise kitap'tır. Ancak (1). örnekte özne konumunda kılıcı rolü Ayşe iken, (2). örnekte özne, konu rolü kitap üyesine yüklenmiş, böylece farklı bakış açıları ortaya çıkmıştır. Bakış açısının belirlenebilmesi için özne işlevinin hangi anlambilimsel role yüklendiği önemlidir. 
$\mathrm{Bu}$ çalışmada Tuva Türkçesinde işteşlik biçimbirimi almış eylemlerin Işslevsel Dilbilgisi'ne göre anlambilimsel yönü incelendiği için anlambilimsel düzlemden bahsetmek gerekir.

\subsection{Anlambilimsel Düzlem}

Bir eylem cümle içinde anlamsal ve sözdizimsel olarak belirli durum ekleriyle işaretlenmiş tamlayıcılara ihtiyaç duyar. İ̧̧levsel Dilbilgisi'nde anlambilimsel işlev durum teriminin yerine kullanılmıştır. Bu yüzden Işslevsel Dilbilgisi'nde nesne durumu, yönelme durumu gibi kavramların yerine kllıcl, etkilenen, konu, hedef, yer, yararlanan ve araç gibi anlambilimsel terimler kullanılmaktadır (Dik 1979: 31-32; Sebzecioğlu 2008: 30; Karabulut 2011: 50; Can 2018: 58).

Dik (1979), bir cümlede İşlevsel Dilbilgisi yöntemine göre incelenen anlambilimsel işlevleri, olay durumlarının tipolojisiyle ilişkilendirerek geliştirmiştir (Koşaner 2009: 82). Olay durumu türleri süreç, durum, hareket ve konum aracılığıyla açıklanır. Olay durumları devingenlik, denetleme, bitmişlik, anlık ve deneyim olmak üzere beş değişkene sahiptir (Dik 1979; 1989). Devingenlik değişkeni bir durumdan başka bir duruma geçişi ya da değişimi sağlayan devingen (Örn. Ahmet ile Osman boğuştular.) ve bir durumdan başka bir duruma değişiklik içermeyen, varlıkların değişmeden aynı kaldıkları devingen olmayan (Örn. Çocuklar kapıda bekleştiler.) değişkenler olarak; denetleme değişkeni de olay durumunda söz konusu üyelerden biri denetleyen konumundaysa denetlemeli (Örn. Kızlar sınıfta gülüşüyorlar.) ve denetleyen konumunda herhangi bir üyenin olmadığı durumlar denetlemesiz (Örn. Arabalar çarpıştı.) olay durumları olmak üzere ikiye ayrılır. Cümle içinde bir eylemin bitmiş olması veya devam etmesi durumu bitmişlik değişkeni (Örn. Ayşe annesiyle karşılaştı.), bir eylemin kısa süreli gerçekleşmesi anlık değişkeni (Örn. Çocuklar kaçıştılar.) ve cümledeki katılımcıların zihinsel ya da duyusal yetilerinde gerçekleşen durumlar deneyim değişkeni (Örn. Öğrenci ögrretmeniyle çatıştı.) ile açıklanır.

Işlevsel Dilbilgisi, dildeki yapısal öğelerin neye göre seçildiğini ve hangi işlev için kullanıldığını bağlama göre belirlemeye çalışır. İşlevsel Dilbilgisi'nde anlam öncelikli olmasına rağmen, biçimsel özellikler de göz ardı edilemez. Bu yüzden Tuva Türkçesi temelinde yapılan bu çalışmada bağlam çerçevesinde ele alınan eylemlerin işteşlik biçimbirimi alması önemlidir. İşteşlik biçimbirimi almış eylemlerin örnek cümleler içinde yüklendiği anlamlar bağlama göre değişiklik gösterebilir.

\section{2. İşteşlik}

Bir gramer kategorisi olarak işteşlik, kılıcının yapma ve olmayı bir başka varlıkla birlikte gerçekleştirmesidir. Eylemde, bir birliktelik veya ortaklaşalık söz konusudur Çokluk ifade eden kılıcı üye geçişsiz eylemlerle kurulduğunda tekliğe dönüşse de işteşlik işlevi sezilir (Trask 1993: 229; Asudeh ve Dalrymple 2006: 23; Crystal 2008: 404-405; Karaağaç 2018: 507-508). Dilbilimsel işteşlik ise bir veya daha fazla olayın birden fazla katılımcıyla eşzamanlı olarak kodlanması gereken bir kavramdır. Dilbilimciler için ilgi çekici olan şey diller arasındaki bu işteşliği kodlamak için kullanılan ifadelerin çeşitliliğidir. Eylemin bildirdiği hareketin birlikte, ortaklaşa, karşılıklı veya yardımlaşarak yapıldığını gösteren ve işteşlik işaretleyicisi olarak 
adlandırılan biçimbirimsel, sözlüksel, sözdizimsel ve anlambilimsel düzlemler bulunmaktadır (Sarıkaya Aksoy 2021: 235).

İşteş yapılar, Işslevsel Dilbilgisi’nin anlambilimsel düzlemine göre katılımcı sayısı, katılımcıların birbiriyle ilişkisi, eylemin gerçekleştiği konum ve zaman gibi değişkenler çerçevesinde incelenir (König ve Gast 2008: 19; Maslova 1999; Siloni 2001).

$\mathrm{Bu}$ çalışmada Tuva Türkçesinde sadece -ş- biçimbirimsel işteşlik işaretleyicisi almış eylemlerin anlambilimsel düzlemde ifade ettiği anlamlar olay durumu türlerine göre ele alınacaktır.

\section{Tuva Türkçesinde İşteşliğin Anlambilimsel Yönü}

Tuva Türkçesinde işteşlik teriminin karşılığı olarak bolçuuşkun glagoldarı terimi kullanılmaktadır. İşteşlik işaretleyicisi ünlü ile biten eylemlerden sonra -ş-, ünsüz ile biten eylemlerden sonra -ş- biçimbirimine (-I-/-U-) yardımcı ünlülerini alarak eklenir (Biçe-ool ve İshakov 1957: 196; İshakov ve Pal'mbah 1961: 282; Sat ve Salzınmaa 1980: 155).

Tuva Türkçesinde işteşlik kategorisi biçimsel tipolojiye göre biçimbilimsel (Uruglar kezek sümeleştiler "Kızlar bir süre birbirlerine nasihat verdiler."), biçimsözdizimsel (Şuptu ulus üne halışkan "Bütün insanlar kaçıştılar."), sözdizimsel (Bis stolduy iyi talazında iyi sandayga udur-dedir olurup aldıvı "Biz masanın iki tarafında iki sandalyeye karşılıklı oturduk.”) ve sözlüksel işteşlik (Men sejee tayılbırlaan men "Ben sana anlatmıştım.”) olarak incelenir (Dorju 2013: 79-88).

Tuva Türkçesinde işteşlik kategorisi, işlevsel tipolojiye göre ise Sarıkaya Aksoy’un (2021) Tuva Türkçesinde Çatı (Karşılaştırmalı Bir İnceleme) adlı doktora tezinde yaptığı inceleme sonucunda anlambilimsel düzlemde doğrudanlık ve dolaylılık değişkenlerine göre ele alınmıştır. Bu çalışmada işteşliğin anlambilimsel yönü belirtilen değişskenler doğrultusunda İşlevsel Dilbilgisi’ne göre aşağıdaki şekilde incelenmiştir.

\subsection{Doğrudan İşteşlik işlevleri}

İşteşliğin ifade ettiği asıl anlamlar karşılıklılık (reciprocity), birliktelik (sociative), topluluk (comitative) ve yardımlaşma (assistive) anlamlarıdır. $\mathrm{Bu}$ anlamlar cümleye doğrudan işteşlik işlevi katar.

\subsubsection{Karşılıklılık Anlamı}

Birden fazla katılımeının bir eylemi karşılıklı olarak yapmaları durumunda ortaya çıkan karşılıklılık anlamı işteşliğin temel anlamlarından biridir. Geçişli ve geçişsiz eylemlerden karş1lıklılık ifade eden eylemler yapılabilir.

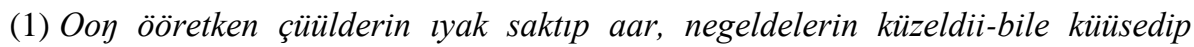

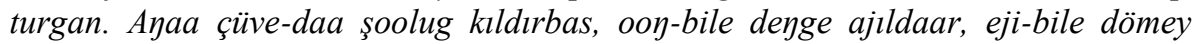
çugaalajır, baştaktançır anıyak, çaraş dergi agayın İlya He baza magadap hanmaan. (DÇ 55) 
“Onun öğrettiği şeyleri iyice öğrenir, arzularını isteyerek yerine getirirdi. Ona çok iş yaptırmaz, onunla aynı anda çalışır, arkadaşı gibi sohbet eder, onunla şakalaşan genç yakışıklı abisi İlya He de onu çok beğenirdi."

(1). Örnekte çugaala-ş- "karşılıklı konuşmak" (<çugaala- "konuşmak") ve baştaktan-l-ş- "karş1lıklı şakalaşmak" (< baştaktan- "şakalaşmak") eylemleri -ş- işteşlik biçimbirimi ile türetilmiştir. Bu örnekte konuşmak ve şakalaşmak eylemlerini birden fazla katılımcı üye karşılıklı olarak gerçekleştirmektedir. çugaala-ş- ve baştaktan-l-şeylemlerinin Kllıcı üyesi 'İlya He', kılıcı üye ile konuşan 'o' Yararlanıcı anlambilimsel işlevini taşımaktadır. Bu eylemler olay durumu türlerinden süreç bildiren, denetlemeli ve devingen olan eylemlerdir. Örnekte görüldüğü gibi konuşma ve şakalaşma eylemleri bitmiş olmayan bir duruma işaret eder.

[çugaala-ş- "birbirleriyle konuşmak, aralarında konuşmak” (Ten 1968: 545): süreç, denetlemeli, devingen olan, bitmiş değil]

[baştaktan-1-ş-: “birbirlerine şaka yapmak” (TolSITY, Tom I, 2003: 234): süreç, denetlemeli, devingen olan, bitmiş değil]

(2) Ol arazında Çoda Noyan Tümen-Çırgal kadınga adaargaan Orukmaa kadın-bile sümeleşgen. (AKM 66)

"O sırada Çoda Noyan Tümen-Çırgal kadını kıskanan Orukmaa ile anlaştı."

(2). örnekte sümele-ş- "karşılıklı anlaşmak" (<sümele- “öğüt vermek”) eylemi -şişteşlik biçimbirimini almış geçişli bir eylemden türetilmiştir. Anlaşma eylemi Çoda Noyan ve Orukmaa arasında karş1lıklı olarak gerçekleşen bir eylemdir. sümele-şeyleminin Kllıcı üyesi 'Çoda Noyan' ve kılıcı üye ile anlaşan 'Orukmaa' ise Yararlanıcı anlambilimsel işlevi üstlenmiştir. Bu eylem olay durumu türlerinden durum bildiren, denetlemeli ve devingen olmayan bir eylemdir. Anlaşma eylemi bitmiş bir eyleme işaret etmektedir.

[sümele-ş- 1. Birbirlerine nasihat vermek, konuşmak; 2. Akıl danışmak, nasihat almak (Ten 1968: 393; TolSITY, Tom II, 2011: 763-764). Yukarıda verilen örnekte kelimenin sözlükteki anlamları dışında "karşılıklı anlaşmak" anlamı taşıdığı metin bağlamı doğrultusunda tespit edilmiştir: durum, denetlemeli, devingen olmayan, bitmiş]

(3) Havan karaan sıgırartır körgüleeş, malgaştıg şalbaadıva metpirẹnedip çoruptar. Inekter sılk sugnu süzüp, bot-bottarınçe kaygajıp turgulaar. (DK 93-94)

"Domuz gözünü çıkartıp gösterince çamurlu suya doğru paytak paytak gittiler. İnekler sığ suda yürüyerek birbirlerine hayretle baktılar."

(3). örnekte kayga-ş- "hayretle bakışmak" (<kayga- "şaşırmak, hayret etmek") eylemi -ş- işteşlik biçimbirimini almış geçişsiz bir eylemden türemiştir. Burada hayretle bakışmak eylemini gerçekleştiren ineklerdir. kayga-ş- eyleminin Kılıcı üyesi 'inekler', ineklerin 'birbirlerine' bakması ise Yararlanıcı anlambilimsel işleve sahiptir. Bakışmak eylemi olay durumu türlerinden süreç bildiren, denetlemeli, devingen olmayan bir eylemdir ve bitmemiş bir eyleme işaret eder. 
[kayga-ş- "birbirlerine hayretle bakmak" (Ten 1968: 219; TolSITY, Tom II, 2011: 40): süreç, denetlemeli, devingen olmayan, bitmiş değil]

(4) Dostay, bajın sogaş kılıp çöpşeereşpişaan, bayırlaşkaş çorupkan. Men baza ooy soondan bazıp ünüpken men. (KKS 70)

"Dostay, başını eğip selamlayarak izin alıp, vedalaşıp gitti. Ben de ondan sonra yürüyüp çıktım.”

(4). örnekte çöpşeere-ş- "birbirinden izin almak" (<çöpşeere- "razı olmak, rıza göstermek") ve bayırla-ş- "vedalaşmak" (<bayırla- "kutlamak") eylemleri -ş- işteşlik biçimbirimini almış eylemlerden türetilmiştir. İzin almak ve vedalaşmak eylemleri katılımcı üyelerin karşılıklı gerçekleştirdikleri eylemlerdir. Bu eylemleri gerçekleştiren Kılıcı üye 'Dostay' dır. çöpşeere-ş- ve bayırla-ş- eylemleri olay durumu türlerinden durum bildiren, denetlemeli ve devingen olmayan eylemlerdir. Buradaki durum yüklemlemesi sadece Dostay'dan ibaret olup "sıfır" anlambilimsel bir işleve sahiptir. Her iki eylem de bitmiş eylemdir. Ancak vedalaşmak eyleminde anlık bir durum da söz konusudur.

[çöpşeere-ş- 1. Birbirine katılmak; 2. Birbirine izin vermek (Ten 1968: 543): durum, denetlemeli, devingen olmayan, bitmiş̧]

[bayırla-ş- "selamlaşmak; ayrılmak için vedalaşmak" (Ten 1968: 86; TolSITY, Tom I, 2003: 206): durum, denetlemeli, devingen olmayan, anlık, bitmiş]

\subsubsection{Birliktelik Anlamı}

Birden fazla katılımcının bir eylemi birlikte gerçekleştirmeleriyle ortaya çıkan birliktelik anlamı daha çok geçişsiz eylemlerden türemekle birlikte az da olsa geçişli eylemlerle de kullanılmaktadır.

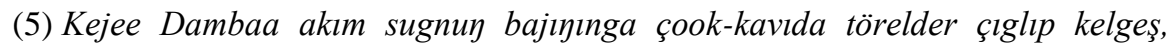
hö̈reşken bis. (KKS 15)

"Akşam Dambaa abimlerin evine yakın bir yerde akrabalarla toplanıp sohbet ettik."

(5). örnekte hööre-ş- "sohbet etmek, konuşmak" (<hööre- "şevkle konuşmak") eylemi -ş- işteşlik biçimbirimini almış geçişli bir eylemden türemiştir ve birliktelik ifade etmektedir. hööre-ş- eyleminin Kllıcı üyesi 'biz' ve 'akrabalarla' ifadesi Yararlanıcı anlambilimsel işleve sahiptir. hööre-ş- eylemi olay durumu türlerinden süreç, denetlemeli, devingen ve bitmemiş bir eylemi göstermektedir.

[hööre-ş- "karşılıklı konuşmak, sohbet etmek" (Ten 1968: 492): süreç, denetlemeli, devingen ve bitmemiş]

(6) Çugaa ereerge, aşak, kaday çerle detkives, uttaşpas bolgan. (DÇ 29)

\footnotetext{
1 "sıfır" anlambilimsel işlev: Eğer durum yüklemlemesinin tek bir üyesi varsa bu üye "sıfır" anlambilimsel işlev olarak adlandırılır ve Ø sembolüyle gösterilir. Durum yüklemlemesinin iki üyesi varsa her iki üye de "sıfır" işlevlidir. (Dik 1979; Ercan, Bakırlı 2009: 48-49).
} 


\section{"Söylemek gerekir ki, yaşlı adam ve kadın (onlara) yardım etmeyip seslerini çıkarmazlarmış."}

(6). örnekte ıttta-ş- "birlikte konuşmak" (<ıttta- "konuşmak, ses çıkarmak") eylemi -ş- işteşlik ve -pas olumsuzluk eki alarak geçişli bir eylemden türetilmiştir. Burada yaşlı adam ve kadının bir konu üzerine konuşmadıkları anlatılmaktadır. ıttta-şeyleminin Kllıcı üyeleri 'yaşlı adam ve kadın'dır. Bu eylem olay durumu türlerinden durum bildiren ve denetlemeli bir eylemi işaretler. Ses çıkarma eyleminin olumsuz şekli kullanıldığı için devingen olmayan bir durum söz konusudur. Buradaki durum yüklemlemesi 'aşak ve kaday' çiftinden oluştuğu için sıfır anlambilimsel işleve sahiptir. Ses çıkarmamak eylemi anlık ve bitmiş bir eylemi bildirir.

[utta-ş- "birçok kişinin gürültü yapıp çığlık atması" (Ten 1968: 602): durum, denetlemeli, devingen olmayan, anlık, bitmiş]

(7) Hün çöön çükten hayaalap kelgen. Ol arazında ögden baza iyi kiji üne halçı kelgen. Olar doraan-na Çagdını tutkaş, hülüy şaap algannar. (TÇI 68)

“Güneş doğudan kızarıp yükselmiş. O sırada evden iki kişi koşarak çıkmışlar. Onlar hemen Çagdı'yı yakalayarak el ve ayaklarını bağlamışlar.”

(7). örnekte halçıp "koşuşmak" (<hall-ş-<hall- "koşmak") eylemi -ş- biçimbirimsel işteşlik işaretleyicisi ile geçişsiz bir eylemden türetilmiştir. Koşma eylemini iki kişinin birlikte yaptıkları anlaşılmaktadır. hall-ş- eyleminin Kılıcı üyesi 'iki kişi', bu iki kişinin uzaklaştıkları yer ‘evden' Kaynak anlambilimsel işleve sahiptir. Koşuşmak eylemi olay dигити türlerinden hareket bildiren, denetlemeli ve devingen olan bir eylemdir. Kılıcı üyelerin koşuşma eylemini anlık bir şekilde gerçekleştirdiği ve eylemin bitmemiş olduğu sezilmektedir.

[hal-ı-ş- “aynı zamanda birçok kişiyi koşturmak" (Ten 1968: 465): hareket, denetlemeli, devingen olan, anlık, bitmiş değil]

\subsubsection{Topluluk Anlamı}

Birden fazla katılımcının bir eylemi toplu olarak gerçekleştirmesi durumudur. Karşılıklılık ve birliktelik anlamları kadar yaygın olarak kullanılmasa da bazı örneklerde işteşliğin topluluk anlamına rastlamaktayız.

(8) Avaşkılar bajınınçe çettinçip algaş kirip kelgende, avazı bajında arjılın uştup kaapkaş, oọ ektinde sumkazın uştup, sanday kırınga salıp kaaş, kuhnyaje çem çıldırı-bile kire beer. (DÇ 99)

"Kardeşler evlerine girdiklerinde, annesi başındaki örtüsünü çıkarıp, omzundaki çantasını sandalyenin üzerine koyup, mutfağa yemek 1sıtmaya giriverir.”

(8). örnekte çettinçip "toplu olarak ulaşmak, yetişmek, girmek” (<çet-tin-i-ş-<çet"ulaşmak, yetişmek") eylemi -ş- işteşlik biçimbirimi alarak geçişsiz bir eylemden türetilmiştir. Kardeşlerin evlerine topluca girdikleri anlaşılmaktadır. çet-tin- $i$-şeyleminin Kılıcı üyeleri 'kardeşler' ve kardeşlerin birlikte ulaştıkları 'evlerine doğru' Yön anlambilimsel işleve sahiptir. Evlerine girmek eylemi olay durumu türlerinden konum bildiren, denetlemeli, devingen olmayan ve bitmiş bir eylemi işaret etmektedir. 
[çettin-i-ş- 1. Birlikte katılmak; 2. Birlikte gitmek (Ten 1968: 530): konum, denetlemeli, devingen olmayan, bitmiş]

(9) Azarlar ${ }^{2}$ çurtunga çedi sıldıs çedi alışk ${ }^{3}$ boop çurttap çoraan çüve-dir. Ol alışkılar arazında aralaşpas, bot-bottarın aygllay körjür amıtannar çüveり irgin. (KK 114)

"Azarlar yedi yıldız yedi kardeş yaşıyorlarmış. O kardeşler birbirlerinden ayrılmıyor, birbirlerini farklı gören canlılarmış."

(9). örnekte arala-ş- "topluca ayrılmak" (<arala- "seçmek, ayırmak") ve kör-ü-ş"görüşmek" (<kör- "görmek, bakmak") eylemleri -ş- işteşlik biçimbirimini alarak geçişli eylemlerden türetilmiştir. İşteş bir yapı taşıyan bu eylemler kardeşlerin topluca birbirlerinden ayrılmadıklarını ve birbirlerini farklı gördüklerini anlatmaktadır. aralaş- ve kör-ü-ş- eylemlerinin Kılıcı üyeleri 'kardeşler'dir. Bu eylemler olay durumu türlerinden durum bildiren, denetlemeli, devingen olmayan ve bitmemiş eylemleri işaret etmektedir. Buradaki durum yüklemlemesi "alışkılar" sıfır anlambilimsel işleve sahiptir.

[arala-ş- 1. Birlikte kontrol etmek; 2. İletişim kurmak; 3. Bir şeyleri seçmek, ayırmak (Ten 1968: 65; TolSITY, Tom I, 2003: 146). Bu kelime yukarıda verilen örnekte sözlük anlamlarının dışında kullanılarak "topluca ayrılmak" anlamı taşımaktadır: durum, denetlemeli, devingen olmayan, bitmiş değil]

[kör-ü-ş- 1. Birbirini izlemek; 2. Birbiriyle tanışmak, görüşmek; 3. Birbirine yardım etmek; 4. Birbirine göz kulak olmak; 5. Birlikte deneyim kazanmak; 6. Birbiriyle yüzleşmek (Ten 1968: 259; TolSITY, Tom II, 2011: 204-205): durum, denetlemeli, devingen olmayan, bitmiş değil]

\subsubsection{Yardımlaşma Anlamı}

Birden fazla katılımcının bir eylemi birbirlerine yardımcı olarak gerçekleştirmeleri durumudur.

(10) Çırık çerde çüü-daa deeş ayaa çöpşeereşpes men. (DÇ 6)

"Dünyada her ne olursa olsun ona yardımcı olmayacağım."

(10). örnekte çöpşeere-ş- "yardımcı olmak” (<çöpşeere- "razı olmak, rıza göstermek”) eylemi -ş- işteşlik biçimbirimini alarak geçişsiz bir eylemden türetilmiştir. $\mathrm{Bu}$ eylemin Kllıcı üyesi 'ben' ve Alıcı üyesi ise 'ona' zamiridir. çöpşeere-ş- eylemi olay durumu türlerinden durum bildiren, denetlemeli, devingen olmayan ve bitmiş bir eylemi işaretlemektedir.

\footnotetext{
2 Azarlar: Tuva mitolojisine göre gökyüzünün bir katmanı olan Kurbustu ülkesinde Azar halkı yaşar. Azarların gökyüzünün yüksek tabakalarında yaşadığına inanılır. Ayrıntılı bilgi için bk. Dyakonova, 1976; Kenin-Lopsan, 1993; Bapaeva, 2008.

${ }^{3}$ Çedi çıldıs çedi alışkı: Tuva mitolojisinde bu ifade "Çedi-Haan" (Yedigir) yıldızıdır. Her bir Tuvalının doğduğu yılın yedi han yıldızlarından biriyle bağlantılı olduğu düşünülür. Bu yedi yıldızın her birinin Samçayan-Amçak, Şugdurjan, Dajıçan, Horvoonçık, Burgan Başkı, Sançı ve Otçı olmak üzere ayrı adı vardır. Ayrıntılı bilgi için bk. Budegeçi, 1995: 636.
} 
[çöpşeere-ş- 1. Birbirine katılmak; 2. Birbirine izin vermek (Ten 1968: 543): durum, denetlemeli, devingen olmayan, bitmiş]

(11) Çoldak-ool ses klasstı doozup algaş, avazınga duzalajıp, oọ kıjın ottular ıyajın beletkep berip turar boldu. (DK 31)

"Çoldak-ool sekizinci sınıfı bitirince annesine yardım edip onun kışın yakacağı odunu hazırlamaya yardım etmiş."

(11). örnekte duzala-ş- "yardım etmek" (<duzala- "yardım etmek" $<$ duza "yardım, fayda") eylemi -ş- işteşlik biçimbirimini alarak geçişsiz bir eylemden türetilmiştir. Burada yardımlaşma eyleminin Kılıcı üyesi 'Çoldak-ool' ve onun yardım ettiği kişi 'annesine' Allcr anlambilimsel bir işleve sahiptir. Bu eylem olay durumu türlerinden hareket bildiren, denetlemeli, devingen olan ve bitmiş bir eylemi işaretlemektedir.

[duzala-ş- 1. Birbirine yardım etmek; 2. Birlikte yardım etmek (Ten 1968: 182; TolSITY, Tom I, 2003: 510): hareket, denetlemeli, devingen olan, bitmiş]

\subsection{Dolaylı İşteşlik İşlevleri}

Tuva Türkçesinde işteşliğin karşılıklılık, birliktelik, topluluk ve yardımlaşma temel anlamlarının dışında bağlama göre başka anlam alanlarında da kullanıldığı görülmektedir. Mücadele etme, meydan okuma, zorlama ve zıtlık anlamları bunlardan bazılaridir.

\subsubsection{Mücadele Etme Anlamı}

Birden fazla katılımcının birbirleriyle mücadele etme, çatışma durumlarını anlatır.

(12) Taanda ooy ınak avazı kançap çaraş eves boldu? Çok, ol kımdan-daa artık çaraş dep çüree ooy bodu-bile margıjıp turgan. (DÇ 100)

"Onun sevgili annesi nasıl çirkin olacak? Hayır, o herkesten güzel diye onun yüreği kendisiyle mücadele etti."

(12). örnekte mücadele etme anlamı taşıyan margl-ş- "mücadele etmek" (<margl"1srar etmek iddia etmek") eylemi -ş- işteşlik biçimbirimini alarak geçişli bir eylemden türetilmiştir. Bu eylem olay durumu türlerinden süreç bildiren, denetlemesiz, devingen olan ve bitmemiş bir eylemi işaretlemektedir.

[margı-ş- 1. Birbiriyle tartışmak; 2. Birbiriyle rekabet etmek (Ten 1968: 289; TolSITY, Tom II, 2011: 332): süreç, denetlemesiz, devingen olan, bitmiş değil]

\subsubsection{Meydan Okuma Anlamı}

Tuva Türkçesinde işteşlik biçimbirimi alarak kullanılan eylemler bazı cümlelerde katılımcıların birbirlerine meydan okumalarını anlatabilir.

(13) Kodanıy iştinge baarga, ulug dalay sug batkan çıdar, ol dalay eriinde kuluzun bar, dalay bile kuluzunnuy arazında üskülejip turar ak, kara iyi buga bar. (AKM 76)

"Çiftliğin içine girince büyük nehir aşağı doğru akıyor, o nehrin kenarında kamışlar var, ırmak ile kamışın arasında toslaşıp duran ak ve kara iki boğa var." 
(13). örnekte üsküle-ş- "toslaşmak" (<üsküle- “çarpışmak, karş1laşmak”) eylemi -şişteşlik biçimbirimini alıp iki boğanın toslaşarak birbirlerine meydan okumalarını anlatır. Bu eylemin Kılıcı üyeleri 'ak ve kara iki boğa'dır ve bu boğaların toslaştıkları yer '1rmak ile kamışın arasında' Yerlik anlambilimsel işleve sahiptir. üsküle-ş- eylemi olay durumu türlerinden hareket bildiren, denetlemeli, devingen olan ve bitmemiş bir eylemi işaretlemektedir.

[üsküle-ş- "birbirine çarpışmak" (Ten 1968: 452): hareket, denetlemeli, devingen olan, bitmiş değil]

\subsubsection{Zorlama Anlamı}

Birden fazla katılımcının bir eylemi gerçekleştirmek için birbirlerine zorluk çıkarmaları durumudur.

(14) Kurbustular ${ }^{4}$ ujup, moorlap keldi! - deeş, haan ara-albatızı-bile kadı barıp teyleer dijip, murnun bılaajıp, baskılajıp kag çazıp çorupkannar-dır evespe. (KK 52)

"Göktekiler uçarak teşrif etti! diyerek han ulusuyla birlikte dua edip, birbirinin önüne geçip üstüne basarak yürümüştür.”

(14). örnekte verilen masal parçasında cansız birtakım varlıkların birbirleri üzerindeki zorlamaları -ş- işteşlik biçimbirimini alan bılaa-ş- "birbirinin önüne geçmek" (<bılaa- "elinden zorla almak") ve baskıla-ş- "birbirinin üstüne basmak" (<baskıla- "basmak") eylemleri ile anlatılmıştır. Burada olay durumu türlerinden bılaaş- eylemi konum bildiren, denetlemeli, devingen, anlık ve bitmiş eylemleri; baskıla-şeylemi ise hareket bildiren, denetlemeli, devingen, anlık ve bitmiş eylemleri işaretler.

[bılaa-ş- 1. Birbirinden almaya çalışmak; 2. Ulaşmak için çabalamak; 3. Tartışmak (Ten 1968: 130; TolSITY, Tom I, 2003: 341). Bu kelime yukarıdaki metinde sözlük anlamlarının dışına çıkarak "birbirinin önüne geçmek" anlamında kullanılmıştır: konum, denetlemeli, devingen, anlık, bitmiş]

[baskıla-ş- 1. Birbirine vurmak; 2. Birbirine yaslanmak (Ten 1968: 93; TolSITY, Tom I, 2003: 223): hareket, denetlemeli, devingen, anlık, bitmiş]

\subsubsection{Zıtlık Anlamı}

Zıtlık anlamı taşıyan cümlelerin biçimbirimsel işteşlik işaretleyicisi almadan önceki durumu ve aldıktan sonraki durumu aynı anlama gelir; ancak kılıcı ve etkilenen öğelerin sözdizimsel konumları değişir:

(15) Izigni seriin solupkan. "Soğuk yerini sıcağa bıraktı."

Konçug izig seriin-bile soluşkan. "Sıcak yerini soğuğa bıraktı (Sıcak, soğukla yer değiştirdi.) (Kuular 2007: 1214).

\footnotetext{
${ }^{4}$ Kurbustu: Tuva mitolojisine göre gögün üst katmanlarından biri olan ülkedir. Burada azar-kurbustular yaşar. Yukarı dünyanın sahibi Kurbustu-Han'dır. Ayrıntılı bilgi için bk. Kenin-Lopsan, 1993; Bapaeva, 2008.
} 
(15). örnekte solu-ş- "yer değiştirmek" (<solu- "değiştirmek”) eylemi -ş- işteşlik biçimbirimini alarak geçişli bir eylemden türetilmiştir ve zıtlık anlamı taşımaktadır. $\mathrm{Bu}$ eylem olay dигити türlerinden durum bildiren, denetlemesiz, devingen olmayan ve bitmiş bir eylemi işaretlemektedir.

[solu-ş- 1. Birbirine (bir şey) vermek; 2. Değiş tokuş etmek; 3. Birbiriyle değiştirmek; 4. İşyerini değiştirmek (TolSıITY, Tom II, 2011: 706): durum, denetlemesiz, devingen olmayan, bitmiş]

\section{Sonuç}

Bu çalışmada, Tuva Türkçesinde işteşlik kategorisinin anlambilimsel yönü Işslevsel Dilbilgisi çerçevesinde olay durumu değişkenlerine göre incelenmiştir. Bir eylemin sahip olduğu yüklemlemeler, belli bir evrendeki varlıkları gösteren üyeler ve bu üyelerin özelliklerini ya da üyeler arasındaki ilişkileri gösteren yüklemlerden oluşur (Dik 1989: 89). Bu yüklemlemeler, yüklemin olay durumunu ortaya çıkarır. Olay durumları anlambilimsel düzlemde devingenlik, denetleme, bitmişlik, anlık ve deneyim gibi farklı türlere ayrılır.

Tuva Türkçesinde işteşlik kategorisi anlambilimsel düzlemde doğrudanlık ve dolaylılık değişkenlerine göre ele alınmıştır. Bu doğrultuda işteşliğin ifade ettiği karşıllklılık (reciprocity), birliktelik (sociative), topluluk (comitative) ve yardımlaşma (assistive) anlamları doğrudan; mücadele etme, meydan okuma, zorlama ve zitlık anlamları ise dolaylı işteşlik işlevlerini oluşturmaktadır. İşteşliğin doğrudan ve dolaylı işlevleri için belirtilen örneklerde olay durumlarının türü somut ve soyut ifadeler doğrultusunda değişiklik gösterebilir. Bu değişiklik özellikle denetlemeli/denetlemesiz. olay durumları ayrımında tespit edilmiştir. Somut ve temel anlamda kullanılan eylemlerin denetlemeli; soyut ve mecaz anlamda kullanılan eylemlerin ise denetlemesiz olay durumu türüne sahip olduğu belirlenmiştir. Ayrıca işteşliğin yardımlaşma anlamı için verilen örneklerde aynı anlama gelen farklı iki eylemin (çöpşeere-ş- ve duzala-ş-) bir örnekte durum olay türüne; diğer örnekte ise hareket olay türüne sahip olduğu görülmüştür. Olay türlerinin devingenlik, bitmişlik ve anlık durumları da eylemlerin cümle içindeki kullanımlarına göre belirlenmiştir.

Tuva Türkçesi edebî metinlerinden seçilen on beş örneklem doğrultusunda yukarıda belirtilen sonuçlar tespit edilmiştir. Farklı kaynakların ve daha fazla örneklemin incelenmesiyle sonuçların zenginleşmesi ve farklı olay durumlarının ortaya çıkması mümkündür.

\section{Kısaltmalar}

AKM Orgu, K. H. (Red.) (1995). Açıtı Kezer Mergen (tooju). Kızıl: Tıvanın

DK Nom Ündürer Çeri, 127s.

DÇ Digınday, B. (2015). Düneki çeleeş (kiska çeçen çugaalar). Kızıl: Tivanın Nom Ündürer Çeri, 124s.

Kenin Lopsan, M. (2015). Deerniy körünçü̈ (toju bolgaş çeçen çugaalar). Kızıl, 145s.

KK Hovalıg, V. Ç. (2015). Kajar koygunak (uruglarga Tiva tooldar). Kiz1l, 143s. 
KKS Monguş, V. (2009). Kadayııga kagdırtkan sen (çeçen çugaalar). Kiz1l, 175s.

TÇI Köjeldey, M. (1995). Töreen çurttan ırakka (toojular, çeçen çugaalar). Kiz1l, 126s.

Ten Tenişev, E. R. (Red.). (1968). Tivaorus slovar'. Moskva.
TolSITY Monguş, D. A. (Red.). (2003). Tolkoviy slovar' tuvinskogo yazıka $(A-Y)$. Tom I. Novosibirsk.

TolSITY Monguș, D. A. (Red.). (2011). Tolkoviy slovar' tuvinskogo yazlka $(K-S)$. Tom II. Novosibirsk.

\section{Kaynakça}

AKSAN, Doğan (1983). Her Yönüyle Dil. Ankara: Türk Dil Kurumu.

Asudeh, Ash; Dalrymple, Mary (2006). "Binding Theory". Encyclopedia of Language and Linguistics (ELL2), 23-31.

BAPAEVA, Janyl Myrza (2008). Tuva Kamlarının Alkışları (İnceleme-Metin-Aktarma). Gazi Üniversitesi Sosyal Bilimler Enstitüsü Yayımlanmamıș Yüksek Lisans Tezi. 182 s.

Biçe-Ool, M. D.; İshaKov, F. G. (1949, 1952, 1957, 1959). Tıva dıldıり grammatikazı. Fonetika bolgaş morfologiya: Ortumak şkolanı̀ 5-6 klasstarga ööredilge nomu. Kızıl: Tıvanın Nom Ündürer Çeri.

Budegeçi, Tamara (1995). "Tuva Şamanlarının Dünya Görüşü Hakkında” (Akt. Ekrem Arıkoğlu). Türk Kültürü, S. 390, Y11. XXXIII, 636-638.

CAN, Özge (Edt.) (2018). Dilbilim Kuramlarl, İki Düzlem Beş Kuram. İstanbul: İthaki.

CRYSTAL, David (2008). A Dictionary of Linguistics and Phonetics. Sixth Edition, USA: Blackwell Publishing.

DiK, Simon C. (1978). Functional Grammar. North-Holland.

DiK, Simon C. (1979). Functional Grammar. New York: North-Holland Publishing Company.

DIK, Simon C. (1989). The Theory of Functional Grammar: The Structure of the clause. Foris Publications.

DuRSun, Sidıka (2018). Türkçede Ettirgen Yapılar. Ankara: Grafiker.

DYAKONOva, V. P. (1976). "Religiozniye predstavleniya altaytsev i tuvintsev o prirode çeloveka". Priroda i çelovek $v$ religioznih predstavleniyah narodov sibiri i severa. $\mathrm{L}$.

EGGINS, S. (1994). An Introduction to Systemic Functional Linguistics. London and New York: Continuum.

Halliday, M. A. K.; Mathiessen, C. (2004). An Introduction to Functional Grammar. New York: Hodder Arnaud.

İsHAKOv, F. G.; PAL'MBAH, A. A. (1961). Grammatika tuvinskogo yazıka. Moskva.

KARAAĞAÇ, Günay (2018). Dil Bilimi Terimleri Sözlüğü. Ankara: Türk Dil Kurumu.

Karabulut, Ferhat (2011). Türk Dilinde Dünya Dillerinde Edilgen Yapı Tipolojisi. Ankara: Grafiker.

Kenin-Lopsan, Mongus (1993). Magiya Tuvinskih Samanov. Kız1l.

KoŞANER, Özgün (2009). "Dilsel Temsilleștirme Aracı Olarak Yüklemleme". Dokuz Eylül Üniversitesi Sosyal Bilimler Enstitüsü Dergisi, Cilt: 11, Say1: 4, 73-89.

KÖNiG, Ekkehard; GAST, Volker (2008). "Reciprocity and Reflexivity: Description, Typology and Theory". Reciprocals and Reflexives: Theoretical and Cross-linguistic Explorations. Trends in Linguistics, Berlin: de Gruyter Mouton, 1-31.

MASLOVA, Elena (1999). "Reciprocals and Set Construal". Frajzyngier and Curl, 161-179.

Monguş, D. A. (Red.). (2003). Tolkoviy slovar' tuvinskogo yazıka (A-Y). Tom I. Novosibirsk.

Monguş, D. A. (Red.). (2011). Tolkovly slovar' tuvinskogo yazıka (K-S). Tom II. Novosibirsk.

MusaOĞLu, Mehman (2003). "Türkçenin İşlevsel Dilbilgisi ve Metin Kompozisyonu". Dil Dergisi, $22-40$.

NUYTS, J. (1983). "On the Methodology of a Functional Language Theory". Advances in Functional Grammar. Dordrecht. 369-387.

SARIKAYA AKSOY, Tuğba (2021). Tuva Türkçesinde Çatı (Karșılaștırmalı Bir İnceleme). Gazi Üniversitesi Sosyal Bilimler Enstitüsü Yayımlanmamış Doktora Tezi. 378s.

SAt, Ş. Ç.; SAlzinmaA, E. B. (1980). Amgı Tıva Litaraturlıg Dıl. Kızıl: Tıvanıı Nom Ündürer Çeri. 
SEBZECioĞLu, Turgay (2008). Türkçede Edilgenlik. Dokuz Eylül Üniversitesi Sosyal Bilimler Enstitüsü Dilbilim Anabilim Dalı Yayımlanmamış Doktora Tezi, 388s.

SILONI, Tal (2001). "Reciprocal Verbs". Proceedings of IATL, 17.

TENișEv, E. R. (Red.). (1968). Tiva-orus slovar'. Moskva.

TRASK, R. Lawrence (1993). A Dictionary of Grammatical Terms in Linguistics. England: Routledge. 